\title{
Induction of ovulation in the pipistrelle bat, Pipistrellus pipistrellus
}

\author{
P. A. Racey* \\ Wellcome Institute of Comparative Physiology, Zoological Society of London, \\ Regent's Park, London NW1 4RY, U.K.
}

The ovaries of hibernating bats were studied by Wimsatt (1944) who showed that the follicle destined to rupture in spring was recognizable in the ovary of Myotis lucifugus before hibernation began the previous autumn. Such a follicle has been observed in all hibernating vespertilionid bats subsequently examined, and its specializations have been described by Wimsatt \& Parks (1966). Premature arousal from hibernation in the second half of winter frequently results in rupture of this follicle and subsequent pregnancy, but exogenous hormones are usually required to induce ovulation in the first half of winter. Ovulation induction has been achieved with several pituitary hormones (Wimsatt, 1960), and some steroids (Herlant, 1954; Ramaswami \& Anand Kumar, 1966). The difficulty of drawing conclusions from these experiments is exacerbated by the wide variation in the doses of hormones administered to animals of approximately the same size, e.g. doses of HCG ranging from 0.5 i.u. (Skreb, 1955) to 100 i.u. (Sluiter, Bels $\&$ van Oordt, 1952) have been administered to animals weighing 10-25 g. Hibernating or torpid animals are generally unresponsive to hormonal stimulation and only those that are aroused will ovulate (Wimsatt, 1960). In previous work, however, there has been no attempt to standardize the conditions of arousal, and it is likely that these conditions would affect events subsequent to ovulation, particularly the formation and maintenance of the CL.

The present experiments were therefore undertaken to devise a regimen which would induce ovulation in the pipistrelle bat, Pipistrellus pipistrellus, and permit the initiation of pregnancy in the first half of the hibernation period so that the fertilizing capacity of spermatozoa throughout their prolonged period of storage in the female reproductive tract (Racey, 1975) could be studied.

Most of the 117 bats used in the study were captured when pregnant or lactating. Animals with different histories were allocated equally to groups. Wild-caught pipistrelles seldom mate in captivity, and the animals used in these experiments were not therefore inseminated. Only parous animals were used since the ovaries of nulliparious females contain no outstanding follicle. Animals were transferred from the batroom (an artificial hibernaculum: Racey, 1970) to the laboratory on 23 October and maintained, in a constant environmental temperature of $20^{\circ} \mathrm{C}$ with food freely available, for various periods before injection (Table 1). Compared with the reduced food supply and low environmental temperature obtaining in the batroom during winter, these conditions were designed to simulate those associated with arousal from hibernation and natural ovulation in spring. The HCG (Pregnyl: Organon) and LH (NIH-LH-S1) were reconstituted in $0.9 \% \mathrm{NaCl}$ and injected as a single i.p. dose. Control groups were maintained in the same conditions and were injected with $0.9 \% \mathrm{NaCl}$.

Animals were killed by decapitation $48 \mathrm{hr}$ after injection. The reproductive tracts were dissected, fixed in Bouin's fluid, dehydrated, cleared, embedded in paraffin wax, serially sectioned at $5 \mu \mathrm{m}$ and stained with haematoxylin and eosin.

The results are presented in Table 1. There was little difference in the diameter of antral follicles at 2 and 9 days after arousal. However, 15 days after arousal, the ovaries of control animals contained a large number of small antral follicles. The chromosomes were at the metaphase of the second meiotic division and the first polar body had been extruded from the oocytes in the antral follicles of $1 / 7$ control bats aroused for 2 days, $1 / 8$ aroused for 9 days and $8 / 18$ aroused for 15 days, indicating that ovulation was increasingly imminent.

\footnotetext{
* Present address: Department of Zoology, University of Aberdeen, Aberdeen, AB9 2TN, U.K.
} 
Table 1. The induction of ovulation and mean $( \pm$ S.D. ) diameters $(\mu \mathrm{m})$ of follicles and corpora lutea in pipistrelle bats aroused from hibernation and treated with gonadotrophins

\begin{tabular}{|c|c|c|c|c|c|c|c|}
\hline \multirow[b]{2}{*}{$\begin{array}{l}\text { Days of } \\
\text { arousal } \\
\text { before } \\
\text { death }\end{array}$} & \multirow[b]{2}{*}{ Treatment } & \multirow[b]{2}{*}{$\begin{array}{c}\text { No. of } \\
\text { bats }\end{array}$} & \multirow[b]{2}{*}{$\begin{array}{l}\text { No. with } \\
\text { ovulable } \\
\text { follicles }\end{array}$} & \multirow[b]{2}{*}{$\begin{array}{c}\text { No. } \\
\text { ovulating } \\
(\%)\end{array}$} & \multirow[b]{2}{*}{$\begin{array}{l}\text { Antral } \\
\text { follicles } \\
\text { (no.) }\end{array}$} & \multicolumn{2}{|c|}{ Corpora lutea } \\
\hline & & & & & & $\begin{array}{c}\text { External } \\
\text { diam. } \\
\text { (no.) }\end{array}$ & $\begin{array}{c}\text { Difference } \\
\text { between internal } \\
\text { and external } \\
\text { diameter (no.) }\end{array}$ \\
\hline 2 & 5 i.u. HCG & 10 & 8 & $6(75)$ & $366 \pm 80$ & $356 \pm 34(6)$ & $77 \pm 23(5)$ \\
\hline 2 & 0 (controls) & 9 & 8 & $0(0)$ & $403 \pm 15$ & & \\
\hline $\begin{array}{l}9 \\
9\end{array}$ & $\begin{array}{l}5 \text { i.u. } \mathrm{HCG} \\
0 \text { (controls) }\end{array}$ & $\begin{array}{r}10 \\
8\end{array}$ & $\begin{array}{l}7 \\
8\end{array}$ & $\begin{array}{l}3(43) \\
0 \quad(0)\end{array}$ & $\begin{array}{l}426 \pm 103 \\
385 \div 34\end{array}$ & $318 \pm 20(4)$ & $92 \pm 20(3)$ \\
\hline 15 & 5 i.u. HCG & 10 & 9 & $3(33)$ & $406 \pm 21$ & $372 \pm 46(3)$ & $65 \pm 10(3)$ \\
\hline 15 & 2.5 i.u. HCG & 10 & 10 & $5(50)$ & $448 \pm 40(6)$ & $346 \pm 23(5)$ & $111 \pm 32(5)$ \\
\hline 15 & 1.25 i.u. HCG & 10 & 10 & $7(70)$ & $438 \pm 28$ (6) & $380 \pm 22(7)$ & $99 \pm 13(6)$ \\
\hline 15 & 0.625 i.u. HCG & 10 & 10 & $3(30)$ & $446 \pm 62(10)$ & $392 \pm 13(3)$ & $75 \pm 4(3)$ \\
\hline 15 & $0.5 \mathrm{mg} \mathrm{LH}$ & 10 & 10 & $4(40)$ & $325 \pm 48(10)$ & $360 \pm 15(4)$ & $79 \pm 7(4)$ \\
\hline 15 & $0.25 \mathrm{mg} \mathrm{LH}$ & 10 & 10 & $4(40)$ & $386 \pm 40 \quad(7)$ & $365 \pm 25(4)$ & $44 \pm 6(4)$ \\
\hline 15 & $0.125 \mathrm{mg} \mathrm{LH}$ & 10 & 8 & $3(38)$ & $355 \pm 36$ (6) & $331 \pm 37(3)$ & $100 \pm 21(3)$ \\
\hline 15 & 0 (controls) & 10 & 8 & $0(0)$ & $249 \pm 17(18)$ & & \\
\hline
\end{tabular}

The oocytes of animals injected with gonadotrophins were smaller than those of controls and, with 5 exceptions, development had proceeded to metaphase of the second meiotic division, with extrusion of the first polar body. The mean diameter of the oocytes in the unruptured antral follicles of gonadotrophin-stimulated animals was $68 \mu \mathrm{m}(n=52)$ and that of ovulated oocytes was $65 \mu \mathrm{m}$ $(n=35)$. In control animals, the mean diameter of the oocytes in which the second metaphase spindle was found was $71 \mu \mathrm{m}$, and that of oocytes in which the dictyate stage had not been passed was $81 \mu \mathrm{m}$. The difference between the size of oocytes of control and treated animals can thus be attributed to loss of the polar body cytoplasm rather than to premature ovulation of undersized oocytes.

In animals which had ovulated, the developing $C L$ was in most cases characterized by hypertrophy of the thecal cells, but the degree of hypertrophy of the granulosa cells was much more variable, and there was no correlation between the extent of hypertrophy and the treatment (Table 1). A solid CL was formed in only 4 animals.

In hibernating bats, LH-secreting cells regress after parturition and resurgence of activity is associated with arousal from hibernation in spring. However, Herlant (1968) has reported that during hibernation small islands of slightly active LH cells can be seen with the electron microscope. The increasing ease with which ovulation and subsequent pregnancy can be induced by prolonged arousal from hibernation without the stimulus of exogenous gonadotrophins during the second half of hibernation (Guthrie \& Jeffers, 1938) indicates that such arousal is a necessary prerequisite for the resurgence of full activity of the LH cells. Although ovulation did not occur in the present experiments in animals that were aroused from hibernation but received no gonadotrophins, the increased incidence of the first polar body 2 weeks after arousal suggests that it was imminent.

It has been suggested that if conditions in temperate countries were to change so that mild winters and the consequent abundance of food no longer necessitated hibernation in insectivorous bats, then ovulation and development of the young would follow copulation in autumn (Baker \& Bird, 1936). To date, the only evidence in favour of this hypothesis are the reports by Zondek (1933) and Caffier \& Kolbow (1934) of pregnancies in single unspecified bats in December, and births in November of the North American vespertilionid bat, Eptesicus fuscus, maintained at a constant $27^{\circ} \mathrm{C}$ (J. Simmons, personal communication). Ovulation may be induced during this time with exogenous gonadotrophins and a dose of 1.25 i.u. HCG administered 13 days after arousal from hibernation has resulted in a $70 \%$ ovulation rate in pipistrelle bats. Although development of the CL has been initiated in these animals, it remains to be discovered whether the treatment results in a resurgence of pituitary activity sufficient to maintain pregnancy. 
This work was supported by the World Health Organization.

\section{References}

BAKER, J.R. \& BIRD, T.F. (1936) The seasons in a tropical rain-forest (New Hebrides): Part 4. Insectivorous bats. (Vespertilionidae and Rhinolophidae). J. Linn. Soc. Zool. 40, 143-161.

Caffier, P. \& Kolbow, H. (1934) Anatomisch-physiologische Genitalstudien an Fledermäusen zur Klarung der therapeutischen Sexualhormonwirkung. $Z$. Geburtsch. Gynäk. 108, 185-235.

GuTHRIE, M.J. \& JeFFERS, K.R. (1938) The ovaries of the bat Myotis lucifugus lucifugus after injection of hypophyseal extract. Anat. Rec. 72, 11-36.

Herlant, M. (1954) Influence des oestrogènes chez le Murin (Myotis myotis) hibernant. Bull. Acad. r. Belg. 40, 408-415.

Herlant, M. (1968) Cycle sexual chez les chiroptères des regions tempérées. In Cycles génitaux saissoniers des Mammifères sauvages, pp. 111-126. Ed. R. Canivenc. Masson, Paris.

RACEY, P.A. (1970) The breeding, care and management of vespertilionid bats in the laboratory. Lab. Anim. 4, $171-183$.

RACEY, P.A. (1975) The prolonged survival of spermatozoa in bats. Biol. J. Linn. Soc. 7, Suppl. 1, 385-416.

Ramaswami, L.S. \& ANAND KUMAR, T.C. (1966) Effect of exogenous hormones on the reproductivestructures of the female bat Rhinopoma during the non-breeding season. Acta anat. 63, 101-123.

SKREB, N. (1955) Influence des gonadotrophines sur les noctules (Nyctalus noctula) en hibernation. $C$. $r$. Séanc. Soc. Biol. 149, 71-74.

Sluiter, J.W., BeLs, L. \& VAN OORDT, G.J. (1952) The reproductive organs of female bats (Myotis myotis) following administration of large doses of gonadotrophins during the hibernation period. Acta endocr., Copenh. 9, 258-270.

WimsatT, W.A. (1944) Growth of the ovarian follicle and ovulation in Myotis lucifugus. Am. J. Anat. 74, 129-173.

WimsatT, W.A. (1960) Some problems of reproduction in relation to hibernation in bats. Bull. Mus. comp. Zool. Harv. 124, 249-267.

WimsatT, W.A. \& Parks, H.F. (1966) Ultrastructure of the surviving follicle of hibernation and of the ovumfollicle cell relationship in the vespertilionid bat Myotis lucifugus. Symp. zool. Soc. Lond. 15, 419-454.

ZONDEK, B. (1933) Action of folliculin and prolan on the reproductive organs of the bat during hibernation. Lancet ii, 1256-1257.

Received 22 September 1975 